\title{
Creating World-Wide Web bulletin boards to enhance current awareness services
}

\author{
P.A. van Brakel * \\ Department of Information Studies, Rand Afrikaans University, P.O. Box 524, Auckland Park, 2006 Republic of South Africa \\ pavb@info.rau.ac.za \\ H.C. Potgieter \\ P.O. Box 490, Auckland Park, 2006 Republic of South Africa \\ carina.potgieter@pixie.co.za
}

Received March 1997; accepted March 1997

\begin{abstract}
Various approaches and techniques have been developed over the years by information services to enable them to render effective current awareness services to their clients or end-users of information. Of these services, computerized SDI services probably present the most important breakthrough. By storing interest profiles on a specific database of an international database host such as KR Dialog or DataStar, these systems are able to e-mail the results (a list of relevant references) to the end-user regulary, for example, on a monthly basis. The research reported here moved further, by investigating the unexplored possibilities of the Internet's World-Wide Web in rendering current awareness services. It was established that an electronic bulletin board could effectively be created on a Web-based home page. The broad needs of a group of staff members employed by the South African Broadcasting Corporation were used to create a prototype bulletin board and to test the hypothesis that such an approach could improve the current state of affairs regarding current awareness services. The prototype was successfully created, using a prescribed methodology and culminating into a hypertext and hypermedia current awareness service.
\end{abstract}

\begin{abstract}
Verskillende benaderings en tegnieke is die afgelope aantal jare deur inligtingsdienste ontwikkel om hulle in staat te stel om effektiewe aktualiteitsdienste te lewer aan kliënte en eindgebruikers van inligting. Uit hierdie pogings verteenwoordig gerekenariseerde SDI-dienste waarskynlik die belangrikste deurbraak. Deur belangeprofiele op 'n spesifieke databasis van 'n internasionale databasismakelaar soos KR Dialog of DataStar te berg, het dit moontlik geword om die resultaat ('n lys van relevante verwysings) op gereelde basis (bv. maandeliks) per elektroniese pos aan die eindgebruiker te stuur. Die navorsing waaroor hier berig word, het een stap verder gevorder, deurdat ondersoek ingestel is na die onontginde moontlikhede wat die Internet se World-Wide Web bied om aktualiteitsdienste te verbeter. Daar is vasgestel dat 'n elektroniese kennisgewingbord effektief met behulp van 'n Webgebaseerde tuislêer ontwikkel kan word. Die breë behoeftes van 'n aantal personeellede wat by die South African Broadcasting Corporation werksaam is, is gebruik om 'n prototipe kennisgewingbord te ontwikkel. Sodoende kon die hipotese getoets word of so 'n toepassing 'n bydrae kan maak om die huidige stand van sake ten opsigte van aktualiteitsdienslewering te verbeter. Die prototipe is suksesvol geskep deur gebruik te maak van 'n standaardmetode om Webomgewings te ontwikkel. Dit het uitgeloop op 'n nuwe benadering om 'n kennisgewingbord in die vorm van 'n hiperteks- en multimediafasiliteit daar te stel.
\end{abstract}

*Author to whom correspondence should be addressed.

Even though the World-Wide Web (WWW) has had only three to four years to develop into an effective Internet navigator, it is already recognized as a very important information infrastructure. Its growth ratio, for example in terms of sites, number of pages or information in multimedia format, already exceeds that of every other Internet navigator, including Archie, Gopher or WAIS. In fact, these navigators, as well as services such as FTP and Telnet, are increasingly becoming accessible through any of the user-friendly, graphical browsers such as Internet Navigator or Netscape. Furthermore, because of the diverse nature of the information being published, the Web has already established itself as a powerful information resource for all categories of information, from general information to highly technical and scientific data.

Owing to its phenomenal growth rate, a need developed for research from various departure points and at various levels or stages of information processing and retrieval. These range from the information input stage (such as the planning and creation of hypertext nodes, design and maintenance of home pages) to the output stage (such as the evaluation of the search quality of search engines, designing interfaces to databases, and incorporating Web activities into an organization's Intranet). One area that has not been investigated, but could play an important role in improving the quality of information services to end-users, is that of rendering current awareness services by using one or more elements of the WWWs infrastructure.

Taking into account the fast-growing number of Web sites (estimated at 500000 by the end of 1997) each consisting of a unique home page and intricate network of hypertext nodes, it could be an extremely valuable undertaking to establish a link from one of the higher levels of a site's home page to a set of pages providing access to the current awareness service of a specific company. The end-user of a current awareness service can then establish a link from these pages to his/her own personal pages, thus obtaining easy access to the Web environment which specializes in announcing recent publications on a given topic. The problem of document delivery support can also be addressed, namely by adding a link at 
each reference or information item to one of the many available electronic delivery services, such as UnCover, EBSCOdoc and Swetscan or UMI (a comprehensive discussion of these services are available in Price, Morris \& Davies 1996). The end-user can then either personally order the full text of a specific document, or fill in a form to request the information service or library to order a specific reference.

In a typical organization, decision makers seldom have the time or the opportunity to browse through new information sources on a regular basis. A current awareness service fills exactly this void by keeping end-users updated on new information and developments in their fields of interest. Using the WWW goes one step further by providing a current awareness and, specifically, an SDI service directly to the end-user workstation. Furthermore, the now familiar Webbased infrastructure, as well as user-friendly browsers, multimedia support and multiple Web sites, is idealy suited for the next generation of SDI services: electronic filters, electronic agents and a new concept, namely Web casting.

Filtered information services can be defined as one that electronically filters or screens masses of (especially) business information, providing, as main purpose, a few highly relevant decision-ready articles per day (McCleary 1994:33). Electronic agent software was first announced in 1994 in the information science literature. Apart from assisting end-users with routine computer tasks such as scheduling appointments and making travelling arrangements, it also filters electronic mail, locates information and alerts users to investment opportunities (Roesler \& Hawkins 1994:19; Griswold 1996).

Web casting is very similar to or rather an enhancement of intelligent agents, in that a software package, such as The PointCast Network, lets the end-user make a selection from a variety of WWW topics and subtopics, including news, company information and industries, to create a typical SDI interest profile (Hasset 1997; Lidsky 1997). The software then regularly searches and delivers to the end-user's workstation updated reports and images found on the Web, which can then be browsed interactively. While the workstation is idling, its graphical screen saver mode will display hyperlink headlines from previously selected sites. Clicking on an item in the screen saver launches the client and lets the end-user view the search results.

Current awareness services were originally designed to provide information about recent publications to groups (abstracting services, journal circulation, exibitions) as well as to individuals (personal notes, individual contact or selective dissemination). The electronic bulletin board is a new format which was developed in the US to support interest groups on hobbies and local history (Vishnesky 1994:1). The now wellknown subject-orientated lists (or listservs) are good examples of how the electronic bulletin board can be utilized to support the exchange of recent and unpublished (especially informal) information between a group of subject specialists. The bulletin board (in both physical and electronic format) is therefore a public medium which makes messages available to everyone with access to that specific facility (Nickerson 1994:118).

The problem with academic bulletin boards, such as listservs, is that their content is normally targeted towards a broad international community. However, the available listserv software can also be used to accommodate internal groups, for example, within the Intranet of a specific enterprise. Such an internal bulletin board is the ideal facility to render current awareness services to groups sharing the same interests. Titles and abstracts of new publications or other media, as well as short communications such as financial news, can be announced via a list.

This development leads to another and much more advanced approach: the creation of Web pages to act as electronic bulletin boards for a selected group of employees. Not only can references to text-based publications (including full-text sources) be incorporated into such a facility, but information sources in any other format, such as sound, video and graphics, can be integrated as part of the current awareness service. End-users can also create links to a specific page devoted to his/her specialized field of interest.

The question of how such an approach should be planned, implemented and maintained is addressed in this article. A prototype was developed, based on the typical current awareness needs of a group of senior managers of the South African Broadcasting Corporation (SABC). Examples of pages from the prototype are reproduced below.

\section{SABC as experimental environment}

The SABC, with its head office situated in Auckland Park, Johannesburg, and a staff component of approximately 5000, is the largest public broadcaster in Southern Africa. A large variety of multimedia information sources is used by the staff of the SABC. Its reference library was used as a basis for setting up the prototype. The following needs within the SABC environment were determined through a synoptic analysis of the enquiries directed by the users to the SABC reference library over a time period of three months, as well as through conversations with personnel and users of the reference library (Potgieter 1995:40-41):

The broadcasting schedule was dominated by music - up to $90 \%$ of the programme schedule on radio was dedicated to music and related programs. More than 700 hours per year were taken up by entertainment and music programmes on TV. These facts indicate clearly that information on musicrelated events was needed on a daily basis by programme compilers and announcers. The reference library of the SABC received up to 30 different music journal titles and programme compilers found it time-consuming to browse through these national and international publications. All types of music were covered in these journals. Publications received by the SABC reference library included African music, Billboard, Black perspective in music, Blues and soul, Contemporary Christian music, Downbeat, Ethnomusicology, Jazz journal international, Jive magazine, Melody maker, 
Opera, Rolling stones, Singing news, Smash hits, Tempo and Top 40.

Multiple copies of the same publication were on order, because the latest issue was always high in demand. Especially popular was the information published in Billboard. At that time eight copies of every issue of the publication were ordered. This international publication is published on a weekly basis and contains information on the top sellers of all kinds of music and videos in various countries. Music types published in this publication are grouped accordingly to categories, for example, jazz hits, best singles, best sales, dance country and pop music (rock-and-roll). This publication guides program compilers on which music to include in programmes on Radio and TV.

Another identified need was access to journal articles and newspaper reports on the SABC published on a regular basis in the media. As the SABC is currently the largest broadcaster in SA, it is obvious that news items in journals and newspapers on events at the SABC will appear almost daily. It is therefore important to the managers and programme compilers to be aware of such items.

Some $\mathrm{SABC}$ radio stations annually publish a compact disc of the popular hits of the year. These CDs are in-house publications that seldom reach the international or even the national market. The SABC also has in-house publications namely a quarterly publication dealing with relevant issues, such as broadcasting and affirmative action and paper-based personnel notices distributed internally at the entrances to the SABC on a daily basis. As many personnel work shifts, they are often unaware of these publications. These information sources contain mostly policy changes or advertisements of available jobs within the SABC and, therefore, it is not necessary to distribute these documents externally.

The general needs of the SABC's personnel can therefore be summarized as follows:

- Information from Billboard;
- Newspaper reports and journal articles dealing with the $\mathrm{SABC}$ and other related topics; and

- In-house publications of the SABC.

It is important to note that traditional electronic bulletin boards do not have the same potential and graphical impact as Web-based bulletin boards. The latter support colour and multimedia, can be fully incorporated into an Intranet or Extranet (when certain external clients are allowed access to the current awareness pages), and end-users can establish links from their personal home pages to those meant for current awareness or store the URLs as bookmarks.

\section{Planning phases}

When planning the Web-based electronic bulletin board, the following phases were set up according to the guidelines of Lemay (1995:26-45). The top-down methodology, as devised by Artz (1996), reflects a more comprehensive approach in designing a home page. Although his methodology was only published after completion of this research, it is incorporated here where applicable, as his approach is one of the most detailed being published to date.

\section{Phase 1: Problem statement}

The point of departure is of course to determine the kind of user who would be using the current awareness service. The target group of this project was senior staff members of the SABC who were interested in various music-related issues and full-text articles that contain information on the organization and the mission of the organization, for example, broadcasting.

\section{Phase 2: Main ideas}

Lemay (1995:30) suggests that, with the aim and target group in mind, the current awareness information should be categorized into broad ideas. Artz (1996:69) calls this phase the conceptual design. Related concepts or main ideas can then be grouped within certain broad headings and related pieces

Table 1 Motivation for including a specific option

\begin{tabular}{|l|l|}
\hline \multicolumn{1}{|c|}{ Option } & \multicolumn{1}{c|}{ Reasons for selection } \\
\hline $\begin{array}{l}\text { Option 1- What is new at the } \\
\text { SABC this week? }\end{array}$ & $\begin{array}{l}\text { Full text journal articles and newspaper reports were scanned in to demonstrate that } \\
\text { in-house publications could be distributed via a Web page }\end{array}$ \\
\hline Option 2 - New CDs available & $\begin{array}{l}\text { Multimedia files, for example sound, were added and linked to text files, to emphasise } \\
\text { the hypermedia component of WWW }\end{array}$ \\
\hline Option 3 - Billboard hits & $\begin{array}{l}\text { An indicative abstract with reference to the complete article was included, because } \\
\text { some of the users did not want to browse through the full text }\end{array}$ \\
\hline Option 4 - Pop music news & $\begin{array}{l}\text { Bibliographical references to relevant information souraces were included to } \\
\text { demonstrate that this option is ideal for those who want to be kept updated of news } \\
\text { and other developments in the area }\end{array}$ \\
\hline Option 5 - Positions available & $\begin{array}{l}\text { WWW is ideal to market the organisation and to advertise job opportunities. The } \\
\text { information service can also market itself via the Web pages }\end{array}$ \\
\hline $\begin{array}{l}\text { Option 6 - Interesting links this } \\
\text { week }\end{array}$ & $\begin{array}{l}\text { To make users aware of related information available on the WWW and the Internet, } \\
\text { a number of new URLs to related databases and homepages can be included on a } \\
\text { weekly basis }\end{array}$ \\
\hline $\begin{array}{l}\text { Option 7 - News, comments and } \\
\text { suggestions }\end{array}$ & $\begin{array}{l}\text { Feedback from users is very important. Their suggestions and comments can only } \\
\text { benefit the current awareness service }\end{array}$ \\
\hline
\end{tabular}


of information grouped under specific topics. These guidelines were followed in organizing the prototype's information into main topics and regrouping them under what eventually became options or hypertext links (Table 1). The extremely wide range of options was selected to illustrate the many possibilities provided by a Web-based bulletin board. The needs of the group of SABC staff involved in the research have shown that, in certain cases, the complete text of an electronic document should be made available, while in other instances, the bibliographic reference and/or the abstract would suffice (options 1, 3 and 4 from Table 1). A main/first Web page is depicted in Figure 1. In addition, newspaper reports and journal articles were selected according to the SABC staff's music needs. Staff notices and in-house SABC publications were also included (Figure2).

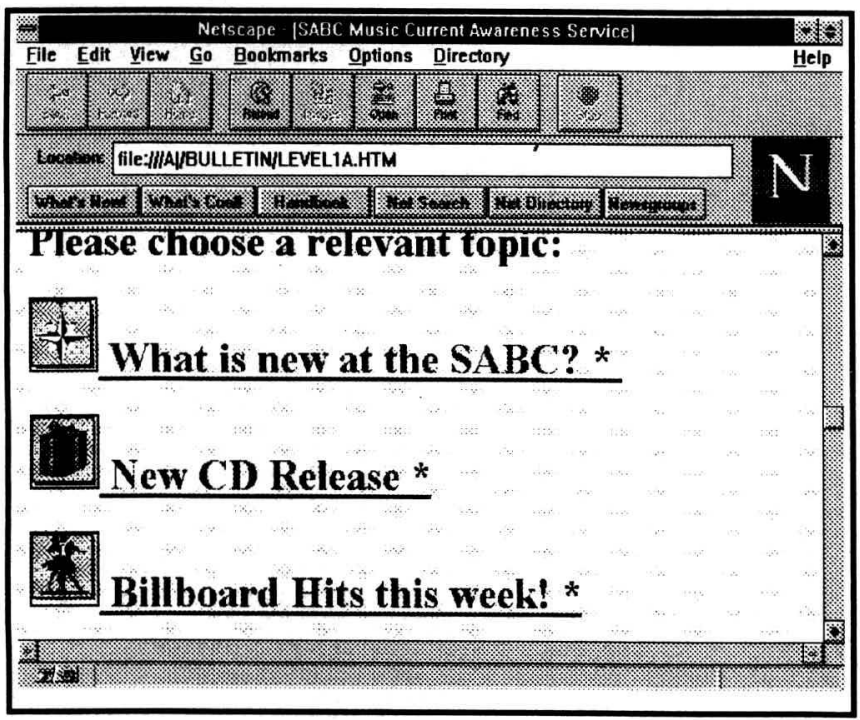

Figure 1 Part of the (first) home page

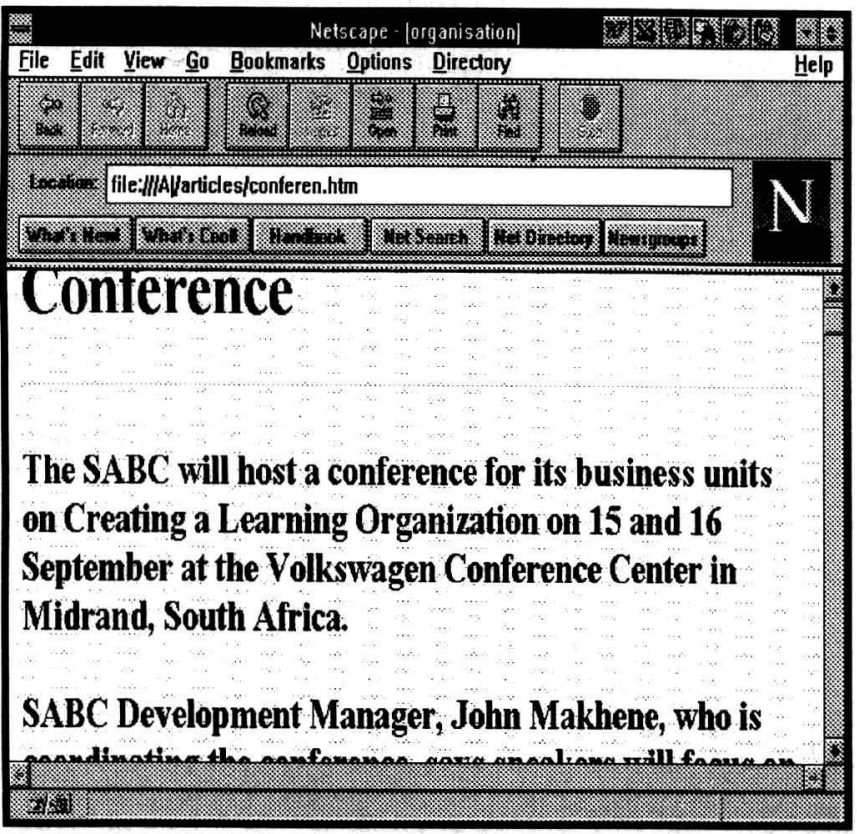

Figure 2 In-house announcements
New end-users to the Internet and WWW are not always aware of applicable or available related external information sources. Option 6 was included to make provision for links to sites containing information such as business and political news, images and weather reports. One of the outstanding features of the Web is its multimedia support. Option 2 was therefore included to illustrate the site's handling of music tracks from recently received CDs.

The marketing of internal services to staff and announcing job opportunities in the SABC via the Web offer excellent possibilities to reach employees (see Option 5). Effective feedback from end-users is an essential feature of any current awareness service. Monitoring changing needs was addressed in the prototype by including Option 7 (news, comments, suggestions). Feedback is stimulated by the inclusion of a Web form as a further option (Figure 3). The completed form is submitted by a staff member via the SABC's e-mail facility.

\section{Phase 3: Organizing information into nodes}

At this stage a clear idea had been developed of what should be included in the current awareness home page. A list of possible subjects was drawn up to assist in organizing the information into a set of WWW pages. The subjects were structured and organized into a set of Web pages. Various approaches to structure were considered, namely, the hierarchical method, linear method, or a combination of the hierarchical and linear methods (Lemay 1995:33-38).

The hierarchical method was decided upon for this prototype, as it was the easiest and most logical method for structuring the information. Hierarchical documents and menus are ideal for online and hypertext-based documents, because the home page will contain the list of main subjects, which will subsequently be divided into sub-pages.

Quaterdeck's WebAuthor for MS Word and Internet Assistant were used as the HTML converters. Both programs are available from $h t t p: / / w w w . q d e c k . c o m$ and http://www. microsoft.com respectively. It was decided to use these programs because of the following reasons:

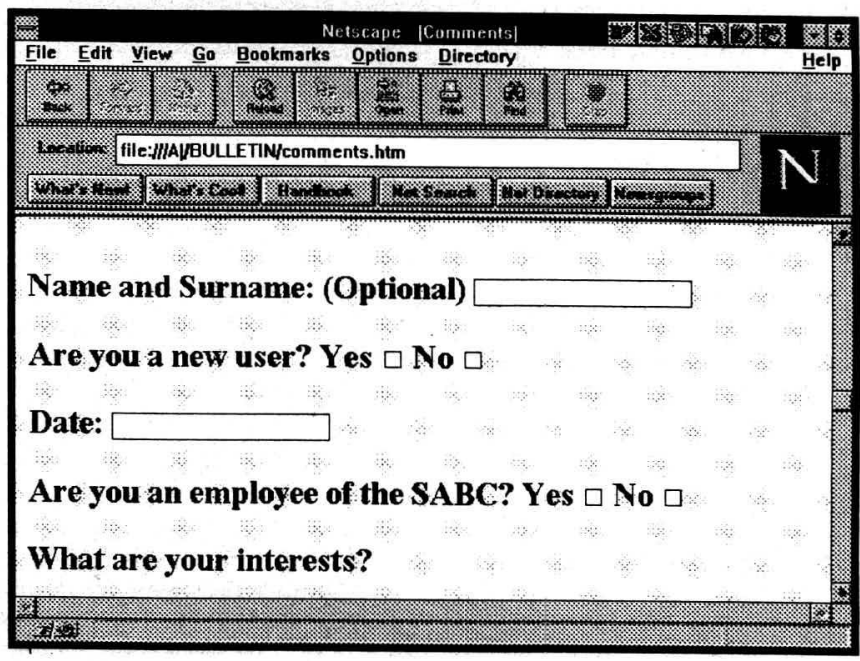

Figure 3 Feedback form 
- Only basic knowledge of HTML is needed to create and develop Web pages.

- Text creation is visible (WYSIWYG).

- A toolbar is available to execute HTML functions quickly and efficiently.

- Support for the designing of forms, menus and links are available.

- Extensive online help is available.

The different documents, references and newspaper clippings were scanned into ASCII format. Multimedia sources were also stored in digital format. The ASCII files were converted to MS Windows files. Hypertext links were created between relevant articles. The focus was on English newspapers and journal articles, as this is the main communication language on the Internet.

\section{Phase 4: Storyboarding}

According to Lemay (1995:42), 'storyboarding' is a concept borrowed from the filming industry. Every event and individual camera shot is sketched and placed into a rough sequence in which the events would develop. A storyboard thus presents a complete structure and plan of the film and enables the editor to position each camera shot within the framework of the whole film.
Storyboarding was effectively used during the development of the Web prototype. See Figure 4. The storyboard provided a rough outline for the structure of the WWW presentation. Main subjects with primary links to text and graphics were presented. It was easier to determine the relationship between the different pages because the position of each individual page in the total environment of the electronic bulletin board was cleary visible. Duplication of the same information was also prevented.

Lemay (1995:44) provides the following guidelines on compiling a storyboard:

- Which theme will dominated a specific page?

Each theme must be associated with a separate page. Related themes are grouped together. Too little or too much information per page should be avoided.

- What is the primary form of navigation (relation) between the pages?

It is important to determine which links are needed to navigate the reader from one page to another.

- What are the alternative forms of access that will be provided?

This guideline refers to access methods or links from an alphabetical index, or a page which acknowledges the authors or compilers of the home page.

- What will appear on the first page of the home page?

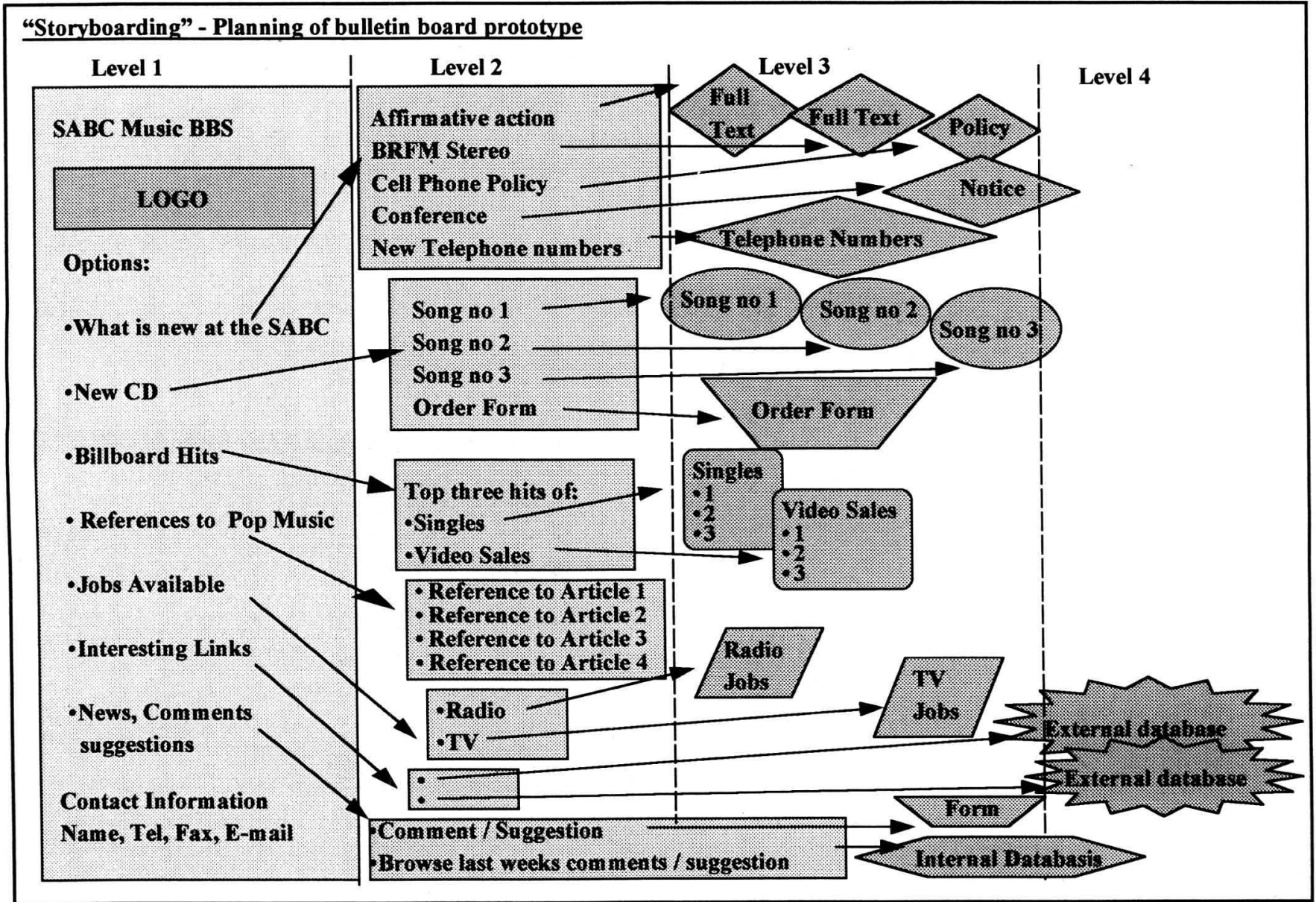

Figure 4 Storyboard 
As the first page is traditionally the starting point of the information available via the WWW file, a list of the various broad options should be included, representing the various subjects selected for the home page site.

- What are the goals?

When planning the framework of the files, it is important to constantly keep the goal of the home page in mind to prevent irrelevant information as well as duplication.

On a more technical level, Artz (1996:69-70) provides the following ideas when developing the storyboard:

- Attempt to balance the storyboard;

- Avoid widths of over nine pages;

- Avoid narrow storyboards of two or less pages;

- Use stepwise refinement rather than trying to get too much on one page;

- A glance at the storyboard should suggest an overall flow of traversal; and

- Show only the major traversals between pages.

\section{Phase 5: Implementation}

The prototype was converted into HTML with WebAuthor and Internet Assistant. All the graphics were stored in either *.gif or *.jpeg formats. PaintShop Pro was used to convert the graphics to these formats. Sound files were stored in *.wav format. Information available on the electronic bulletin board should be as recent as possible. Weekly updates are recommended. Information that does not need regular updates were also included, for example telephone numbers of departments within the organization. Additions should be clearly distinguishable from previous items so that the reader can easily establish which information has been read. A suggestion is to mark the current week's updates with an asterisk. Phrases rather than single words were used to indicate the coverage included in the subject. Abbreviations were avoided as far as possible.

It should be possible for readers to move freely from one relevant item to the next. Page breaks were inserted with care to prevent the splitting of paragraphs. Information such as the name of the bulletin board's editor, telephone number, e-mail address and postal address was considered essential and therefore included on the first page. An option was included to provide staff with an opportunity to send comments and suggestions to the editor.

\section{Phase 6: Testing}

Fry and Paul $(1995: 111,114)$ add a last but essential activity to the methodology. Each and every hypertext link should be tested after it has been created. The prototype was thoroughly tested with various browsers, including Netscape and Mosiac.

\section{Conclusion}

The results of the research reported above, demonstrates clearly the potential of rendering current awareness services via the World-Wide Web. The results also indicate that today's information services can begin to implement the wide scope of possibilities offered by the technical infrastructure, facilities, data and information which is available via the Web. The research concentrated on only one application creating a Web-based bulletin board to render a current awareness service to a homogenous group of clients. The results of the research culminated in a prototype bulletin board, indicating the practical possibilities of such an approach. However, another important contribution of the research was the exploration of the idea that end-users can add the URLs of files created and maintained by the information service to that of their own home page environments. It also indicates that the end-user can create his/her own links to external document delivery services to search and obtain full-text copies of relevant articles.

From the viewpoint of the information intermediary, the Web offers a vast range of application possibilities to explore. By maintaining a personal home page under the banner of the parent organization, the information specialist can communicate with his/her clients through different types of current awareness and SDI services, including informal communication about recent publications, new URLs, feedback forms, notifications of conferences and many more. The advantage of operating in a Web environment is that the references to information (as part of a current awareness service) could now also contain the URLs or hypertext links to full-text sources.

\section{References}

Artz, J.M. 1996. A top-down methodology for building corporate Web applications. Internet research: electronic networking applications and policy, 6(2/3):64-74.

Fry, A. \& Paul, D. 1995. How to publish on the Internet: a comprehensive step-by-step guide to creative expression on the WorldWide Web. New York: Warner.

Griswold, S.D. 1996. Unleashing agents: the first wave of agentenabled products hits the market. Internet world, 7(5):55-57.

Hasset, C. 1977. The PointCast Network. PC magazine SA, 5(1):40.

Lemay, L. 1995. Teach yourself Web publishing with HTML in a week. Indianapolis: SAMS Publishing.

Lidsky, D. 1977. Internet: the Web delivers. $P C$ magazine $S A, 5(2)$ : 63-69.

McCleary, H. 1994. Filtered information services: a revolutionary new product or a new marketing strategy? Online, 18(4):33-42.

Nickerson, R.S. 1994. Electronic bulletin boards: a case study of computer-mediated communication. Interacting with computers, 6(2):117-134.

Potgieter, H.C. 1995. Aktualiteitsdienslewering met behulp van 'n World-Wide Webgebaseerde kennisgewingbord. M Bibl-verhandeling. Johannesburg, Randse Afrikaanse Universiteit.

Price, S.P., Morris, A. \& Davies, J.C. 1996. An overview of commercial electronic document delivery suppliers and services. The Electronic library, 14(6):523-542.

Roesler, M. \& Hawkins, D.T. 1994. Intelligent agents: software servants for an electronic information world (and more). Online, 18(4):19-32.

Vishnesky, D. 1994. The vicious book of BBS's (version 1.01). [Online]. Available URL:http://www.dsv.su.se/ matsljo/ bbslist.html). 